\title{
INFESTATION DENSITY OF LEAFHOPPERS; EMPOASCA DECIPIENS AND OROSIUS ALBICINCTUS AND GREEN BUG; NEZARA VIRIDULA ON SESAME IN FAYOUM
}

\author{
SABRA, I. M. \\ Field Crop Pests Department-Plant Protection Research Institute- Agricultural \\ Research Center- Dokki-Egypt.
}

\begin{abstract}
Field population of Empoasca decipiens Paoli, Orosius albicinctus Dist. and Nezara viridula were evaluated during 2010 and 2011 seasons on sesame; Sesamum indicum L. under Fayoum conditions. Sampled with sweeping net, Empoasca decipiens was relatively higher (132-173/25 double strokes/week) than O.albicinctus (13.6-19.7/25 double strokes/ week). The maximum densities of the former species were 304 and 349 /25 double strokes in 2010 and 2011 seasons, while were 36.5 and 40.5 $/ 25$ double strokes for the $2^{\text {nd }}$ one. On the other hand, infestation with $N$. viridula began with relatively low numbers (2.0-3.3 individual/25 double strokes) and increased gradually to reach its maximum of 56.5 and 72.0 individual/25 double strokes in the $1^{\text {st }}$ and $2^{\text {nd }}$ week of August during 2010 and 2011 seasons, respectively. The estimated population densities of the studied three insects indicated that they became serious pests for sesame in Fayoum.
\end{abstract}

Key words: Population, Empoasca decipiens, Orosius albicinctus, Nezara viridula, sesame.

\section{INTRODUCTION}

Sesame; Sesamum indicum L. is an important oil crop cultivated for oil, paste, cake and flour produced from seeds and is considered a typical crop of small farmers in developing countries. Sesame oil, an important agricultural attribute, reaches $53.583 \%$ in seeds which also contain $26.25 \%$ protein. Sesame cultivations are susceptible to several pest infestations which cause considerable economic damage. Leafhoppers and green bugs in particular are piercing and sucking pests which feed on the cell sap from leaves, flowers and buds leading to curling and redness of leaf margins; yellowing, stunting, and abnormal growth of the plants. Among the various insect pests of sesame, the bug Nezara viridula (L.) and the leafhoppers Empoasca decipiens Paoli and Orosius albicinctus Dist. are the most common, Bhadauria et al., (2000) reported that, $N$. viridula, Empoasca spp. and O. albicinctus are regular pests that appear in large numbers infesting pods and leaves of sesame. The latter species transmits a viral disease from infected sesame plants to healthy ones (Akhtar et al., 2009 and Omidi et al., 2010).

Therefore, the present study was carried out to shed some the light on the populations of these pests on sesame crop under Fayoum conditions.

\section{MATERIALS AND METHODS}

A farmer field of one feddan in Senores district, Fayoum Governorate during 2010 and 2011 seasons was chosen. The experimental area was 1/4 fedden, divided into 4 equal plots, each consists of 48 rows ( $8 \mathrm{~m}$ long and 0.5 $\mathrm{m}$ wide). Sesame seeds (Giza 32 variety) were planted on June, $1^{\text {st }}$ in both

Fayoum J. Agric. Res. \& Dev., Vol.26, No.1, January, 2012 
seasons. The plants received the normal agricultural practices but no insecticides were applied. Sampling started two weeks after plantation and continued weekly to the end of the season using a standard sweeping net (37 $\mathrm{cm}$. diameter and $60 \mathrm{~cm}$. deep). Each sample was 25 double sweeping strokes randomly taken from each plot. The collected insects were placed in polyethylene bags and kept in the freezer for 15 minutes to kill the insects which were later counted and identified according to Sabra (2002) to record data on the chosen studied species, E. decipiens, $O$. albicinctus and $N$. viridula. Statistical analysis with simple correlation (b) between maximum temperature and R.H.\% was done to show their effect on populations of these insects.

\section{RESULTS AND DISCUSSION \\ A. Population fluctuation of $\boldsymbol{E}$. decipiens.}

As shown in table $(1 \& 2)$ infestation of E. decipiens began in the seedlings stage; two weeks after plantation, in relatively few numbers (38.3 individuals/25 double strokes) and gradually increased through the season reaching the highest (304.5 individuals /25 double strokes) in July 20 during the $1^{\text {st }}$ season and 349.3/individuals $/ 25$ double strokes during $2^{\text {nd }}$ season. Thereafter population gradually decreased to reach its lowest (34.0-41.3 individuals $/ 25$ double strokes) at the end of both seasons respectively, at a maximum temperature of $32.9-39.1^{\circ} \mathrm{C}$ and an average relative humidity of $55.0-60.6 \%$. The highest densities during the $3^{\text {rd }}$ week of July was at max. temps. $35.2-40.9^{\circ} \mathrm{C}$ and $51.9-57.2 \%$ R.H for the two seasons, respectively. Statistical analysis in table (3), revealed that no correlation was evident between maximum temperature or mean percent of relative humidity and populations of $E$. decipiens in the $1^{\text {st }}$ season because weather conditions were around the optimum levels, while in $2^{\text {nd }}$ season the population was significantly positively correlated to maximum temperature but was not affected by RH\%. In this respect, Sewify et al, (1996) reported also that, the maximum population density of E. decipiens occurred on cotton during August and September, and in Assiut, Ali (1996) reported that, this insect was the most abundant on sesame field representing $57.89 \%$ of total pests population found.

\section{B. Seasonal fluctuation of $O$. albicinctus:}

As shown in table $(1 \& 2)$ the infestation of sesame plants with this species began at a low intensity as 3-4 individuals/25 double strokes, 4 weeks after plantation at $34.6-39.4^{\circ} \mathrm{C}$ and $44.4-55.5 \%$ R.H. The infestation gradually increased throughout the season showing two peaks in each season.

The respective highest densities were 36.5 - 40.5 individual $/ 25$ double strokes in the $1^{\text {st }}$ week of September and the $4^{\text {th }}$ week of August at max. temp. $34.1-39.7^{\circ} \mathrm{C}$ and average R.H. $47.4-59.3 \%$. The population density was higher in 2011 than in 2010 season with mean catch of 19.7 and 13.6 individual/25 double stokes/week, respectively, due to the effect of maximum temperature which were 39.7 and $34.5^{\circ} \mathrm{C}$, respectively. This leafhopper showed two peaks, the first were moderately; 16.25 and 25.25Individuals/25 double strokes at the $4^{\text {th }}$ and $3^{\text {rd }}$ week of July in 2010 and 2011 season, respectively. The second peak was the highest being 36.5

Fayoum J. Agric. Res. \& Dev., Vol.26, No.1, January, 2012 
INFESTATION DENSITY OF LEAFHOPPERS;

and 40.5 individual/ 25 double strokes at the end of August and the beginning of September of 2010 and 2011 season, respectively. Statistical analysis in table (3), revealed that no correlation were evident between maximum temperature or mean percent of relative humidity and population of $O$. albicinctus in the $1^{\text {st }}$ season. In the second season the population was not affected with maximum temperature but a significant positive correlation with RH\% was evident. In this respect, Serinivasula and Narayanasamy, 1995 in India found that, the sesame sown in April showed high population of $O$. albicinctus. In Assiut, Ali (1996) found that, this species represented $5.47 \%$ of the total catch as the second abundant pest of sesame.

Table 1. Weekly counts ( 25 double strokes x 4 reps.) of $E$. decipiens, $O$. albicinctus and $N$. viridula on sesame in Fayoum during 2010 season.

\begin{tabular}{|c|c|c|c|c|c|}
\hline \multirow[t]{2}{*}{ Inspection date } & \multicolumn{3}{|c|}{ Average $/ 25$ double strokes } & \multicolumn{2}{|c|}{ Weather factors } \\
\hline & E. decipiens & O. albicinctus & N. viridula & Max. temp. & $\mathrm{RH} \%$ \\
\hline June 15 & 38.3 & 0.0 & 2.0 & 33.0 & 54.7 \\
\hline 22 & 62.3 & 0.0 & 6.0 & 37.8 & 61.0 \\
\hline 29 & 97.5 & 4.0 & 11.5 & 34.6 & 55.5 \\
\hline July 6 & 145.3 & 10.3 & 18.5 & 32.7 & 58.3 \\
\hline 13 & 212.8 & 11.0 & 28.3 & 33.4 & 59.4 \\
\hline 20 & 304.5 & 12.5 & 36.3 & 35.2 & 57.2 \\
\hline 27 & 280.0 & 16.3 & 41.8 & 35.7 & 57.8 \\
\hline Aug. 3 & 201.3 & 13.5 & 56.5 & 35.3 & 60.6 \\
\hline 10 & 163.0 & 11.0 & 50.3 & 35.7 & 57.1 \\
\hline 17 & 109.8 & 9.8 & 37.0 & 35.4 & 60.8 \\
\hline 24 & 90.5 & 14.5 & 25.8 & 35.8 & 59.7 \\
\hline 31 & 75.3 & 29.3 & 18.5 & 35.6 & 55.9 \\
\hline Sept. 7 & 51.5 & 26.5 & 12.0 & 34.1 & 59.3 \\
\hline & 34.0 & 21.8 & 6.5 & 32.9 & 60.6 \\
\hline Total & 1866.1 & 185.3 & 350.8 & 487.2 & 817.9 \\
\hline Mean & 133.3 & 12.9 & 25.1 & 34.8 & 58.4 \\
\hline
\end{tabular}

In general, the results showed that, the numbers of $E$. decipiens were clearly higher (1866.1-2421.6) than those of $O$. albicinctus (185.5-276.5). Its obvious that the total mean numbers of E. decipiens represented 8-9 times as $O$. albicinctus may be due to wide spread of first species all the year round and on large scale of hosts than the second. In this respect, Sabra (2002) reported that, E. decipiens attack 36 host plants all the year round, while $O$. albicinctus attack 12 host plants only on the warm months. 
SABRA, I.M.

Table 2. Weekly counts (25 double strokes $\times 4$ reps.) of $E$. decipiens, $O$. albicinctus and $N$. viridula on sesame in Fayoum during 2011 season.

\begin{tabular}{|c|c|c|c|c|c|}
\hline \multirow{2}{*}{$\begin{array}{l}\text { Inspection } \\
\text { date }\end{array}$} & \multicolumn{3}{|c|}{ Average $/ 25$ double strokes } & \multicolumn{2}{|c|}{ Weather factors } \\
\hline & E. decipiens & O. albicinctus & N. viridula & Max. temp. & RH $\%$ \\
\hline June 15 & 42.0 & 0.0 & 3.3 & 39.3 & 41.3 \\
\hline & 74.3 & 0.0 & 8.0 & 38.3 & 46.3 \\
\hline 29 & 102.5 & 3.0 & 13.8 & 39.4 & 44.4 \\
\hline July 6 & 140.5 & 6.8 & 20.5 & 38.7 & 47.1 \\
\hline & 197.5 & 15.3 & 31.3 & 40.6 & 52.0 \\
\hline 20 & 349.3 & 25.3 & 40.0 & 40.9 & 51.9 \\
\hline 27 & 338.0 & 22.0 & 48.3 & 42.0 & 47.4 \\
\hline Aug. 3 & 322.8 & 19.0 & 57.5 & 41.1 & 55.1 \\
\hline 10 & 253.3 & 26.5 & 72.0 & 40.5 & 53.4 \\
\hline 17 & 211.0 & 35.8 & 51.3 & 37.5 & 56.0 \\
\hline 24 & 170.3 & 36.3 & 23.0 & 40.7 & 49.3 \\
\hline 31 & 102.0 & 40.5 & 16.3 & 39.7 & 47.4 \\
\hline Sept. 7 & 76.8 & 28.0 & 9.5 & 38.8 & 51.0 \\
\hline & 41.3 & 17.3 & 5.8 & 38.1 & 55.0 \\
\hline Total & 2421.6 & 275.5 & 400.3 & 555.6 & 697.6 \\
\hline Mean & 173.0 & 19.7 & 28.6 & 39.7 & 49.8 \\
\hline
\end{tabular}

\section{Seasonal fluctuation of $N$. viridula:}

Data presented in table $(1 \& 2)$ revealed that, the infestation with this pest started early, two weeks after plantation, in relatively low numbers 2.0 3.25 inviduals $/ 25$ double strokes at a max. temp. of $33.0-39.3^{\circ} \mathrm{C}$ and average R.H. 41.3 - $54.7 \%$ R.H. whereas the adults migrate from the neighboring fields. The population increased gradually to reach its maximum; 56.5 and 72.0 individuals/25 double strokes in the $1^{\text {st }}$ and $2^{\text {nd }}$ weeks of August at 35.3$40.5^{\circ} \mathrm{C}$ and $53.4-60.6 \%$ R.H. \% during 2010 and 2011 seasons, respectively, then decreased toward the end of the season. The population showed only one peak at the beginning of August in both seasons. Data table (3) of statistical analysis revealed that no correlation were evident between maximum temperature or mean percent of relative humidity and population of $N$. viridula in the $1^{\text {st }}$ season. In the second season the population was not affected with maximum temperature but a significant positive correlation with $\mathrm{RH} \%$ was evident. In this respect, Al-Shannaf (2010) reported that, the seasonal mean numbers of $N$. viridula was 7.93 individuals /100 cotton plant. The relatively high population of $N$. viridula in sesame field may be due to the lowest numbers of its scelionids parasite which sesame leaves act as a repellent of this natural enemy (Turner 1983). In general, the three aforementioned insect populations were relatively higher at the end of the season because sesame plants are harvested before complete dryness to avoid the loss of seed crop.

Fayoum J. Agric. Res. \& Dev., Vol.26, No.1, January, 2012 
INFESTATION DENSITY OF LEAFHOPPERS;

Table 3. Statistical analysis for the effect of the weekly maximum temperatures and R.H.\% on E. decipiens, O. albicinctus and $N$. viridula populations on sesame in 2010 and 2011 seasons.

\begin{tabular}{|c|l|c|c|}
\hline \multirow{3}{*}{ Season } & \multicolumn{1}{|c|}{ Insect } & Max. temp. & RH\% \\
\hline \multirow{3}{*}{2010} & E. decipiens & 0.142 & -0.039 \\
\cline { 2 - 4 } & O. albicinctus & -0.130 & 0.125 \\
\cline { 2 - 4 } & N. viridula & 0.315 & 0.181 \\
\hline \multirow{3}{*}{2011} & E. decipiens & $0.721^{* *}$ & 0.426 \\
\cline { 2 - 4 } & O. albicinctus & 0.188 & $0.543^{*}$ \\
\cline { 2 - 4 } & N. viridula & 0.499 & $0.574^{*}$ \\
\hline
\end{tabular}

REFERENCES

Ali A.G. (1996). Survey of arthropods associated with sesame plants in Assiut Governorate, Upper Egypt. Assiut-Journal-of-Agricultural-Sciences. 1996, 27: 2, 135-145

Al-Shannaf, H.M.H. (2010). Effect of sequence control sprays on cotton bollworms and side effect on some sucking pests and their associated predators in cotton fields. Egypt. Acad. J. biolog. Sci., 3 (1): 221 - 233.

Akhtar K.P., Sarwar G., Dickinson M., Ahmad M., Haq M.A., Hameed S. and Iqbal M.J. (2009). Sesame phyllody disease: its symptomatology, etiology, and transmission in Pakistan. Turk J. Agric. 33 : 477-486.

Bhadauria N.K.S., Bhadauria N.S. and Divedi U.S. (2000). Pest complex of sesame and their status under Gwalior condation. Agric. Sci. Digest, 20 (2):108-109.

Omidi M. Hosseini A.P. Massumi H. and Rahimian H. (2010). Investgation on transmittance status of Orisus albicinctus (Hemiptera: Cicadellidae) as a natural vector of phytoplamas in southeastrn Iran. J. of Plant Pathology, 92 :(2) 531-535.

Sabra I. M. (2002). Species and populations of leafhoppers in Fayoum Governorate with some biological observations. Ph.D. Thesis, Fac. Agric., Cairo Univ., Egypt.

Sewify, G.H.; El Arnaouty, S.A. and Belal, M.H. (1996). The effect of cotton late planting on population densities of sucking insects and their associated predators in Giza region, Egypt. Bull. Fac. Agric., Univ. Cairo, 47: 665-675.

Serinivasula, B. and Narayanasamy, P. (1995). Epidemiolgy of sesame phyllody disease. J. Oilseeds Research 12: (2) 176-179.

Turner J.W. (1983). Influence of plant species on the movement of Trissolcus basalis Woolaston (Hymenoptera: Scelionidae) a parasite of Nezara viridula L. Journal of the Australian Entomological Society. 22: (3) 271-272

Fayoum J. Agric. Res. \& Dev., Vol.26, No.1, January, 2012 
SABRA, I.M.

كثافة الإصابة بنطاط الأوراق Empoasca decipiens و Orosius albicinctus والبقة الخضر اء Nezara viridula على محصول السمسم بمحافظة الفيوم.

$$
\text { إبراهيم مخيمر صبرة }
$$

مركز البحوث الزراعية ، معهد بحوث وقاية النباتات ، الدقي ـ الجيزة ـ مصر

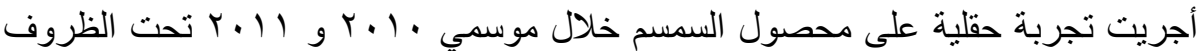

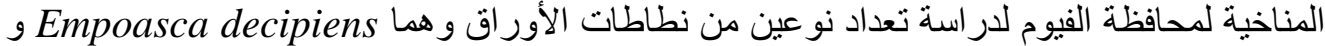
Orosius albicinctus

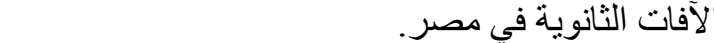

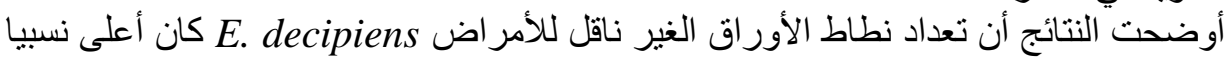

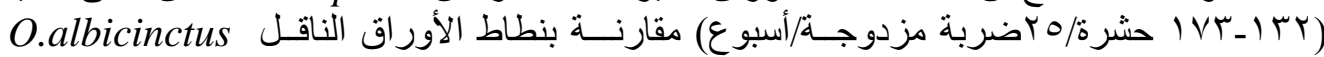

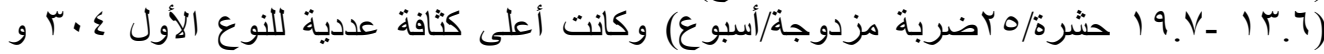

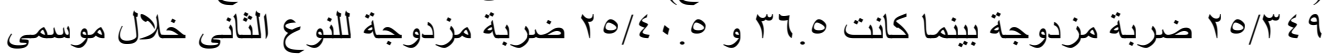

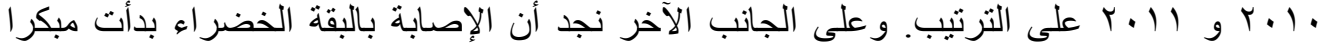

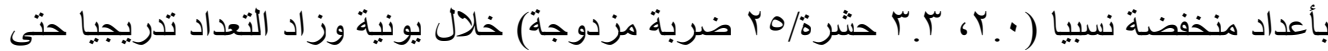

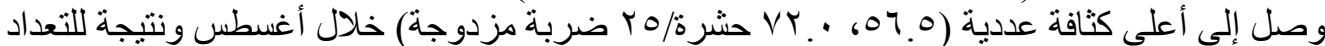

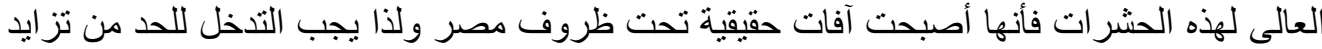
أعدادها على محصول السمسم لتقليل الفقد منه ورفع إنتاجيته. 